\title{
Designing Function-Specific Plant Systems (FSPSs) for Sustainable Urban Development
}

\author{
Katherine E. French ${ }^{1}$ \\ ${ }^{1}$ Department of Plant and Microbial Biology, Koshland Hall, University of California Berkeley, Berkeley, \\ CA 94720
}

Increasingly, architects are looking towards nature to design more sustainable, efficient cities to reduce the environmental impact of urban life. At the moment, plants are incorporated into urban design for conservation or aesthetic reasons. Here, I argue plants can be rationally designed into synthetic systems based on chemical and other functional traits to increase the stability of urban infrastructure, protect native biodiversity, and promote human health while meeting key UN Sustainable Development Goals.

\section{Greening Future Cities}

For millennia, we have imagined what future societies will look like, from Thomas More's Utopia and Aldous Huxley's Brave New World to the artists of the Italian futurismo movement and popular films like Ridley Scott's Blade Runner. Such ideas have also entered the architectural world, most notably with National Geographic's The Cities issue. ${ }^{1}$ This issue depicts what our cities could look like: sustainable, resilient, and beautifully designed. Central to future cities thinking is the concept of biomorphic urbanism: the idea that the natural world can inspire how we design the spaces we inhabit and how our cities function..$^{2-4}$

This push towards sustainable urbanism is sorely needed. Urban populations are set to expand from 3 billion people as of 2000 to 6.4 billion by 2050; areas of greatest growth include sub-Saharan Africa and South and Central Asia (Fig. 1). ${ }^{5}$ Such influxes of humans into urban spaces will create new stresses on transportation infrastructure, housing, water, and use of other natural and non-renewable resources. ${ }^{6}$ This shift in human population dynamics will also impact the natural world. For example, wildlife migration patterns, behavior, and biological processes (like mating and reproduction) will shift with loss of habitats and perturbation of food webs. ${ }^{7,8}$ Urban landcover in biodiversity hotspots is projected to expand by $200 \%$ by 2030 , threatening the continuity of and ecosystem services provided by major global biodiversity hotspots, such as the Eastern Afromontane and Guinean Forests of Western Africa. ${ }^{9}$
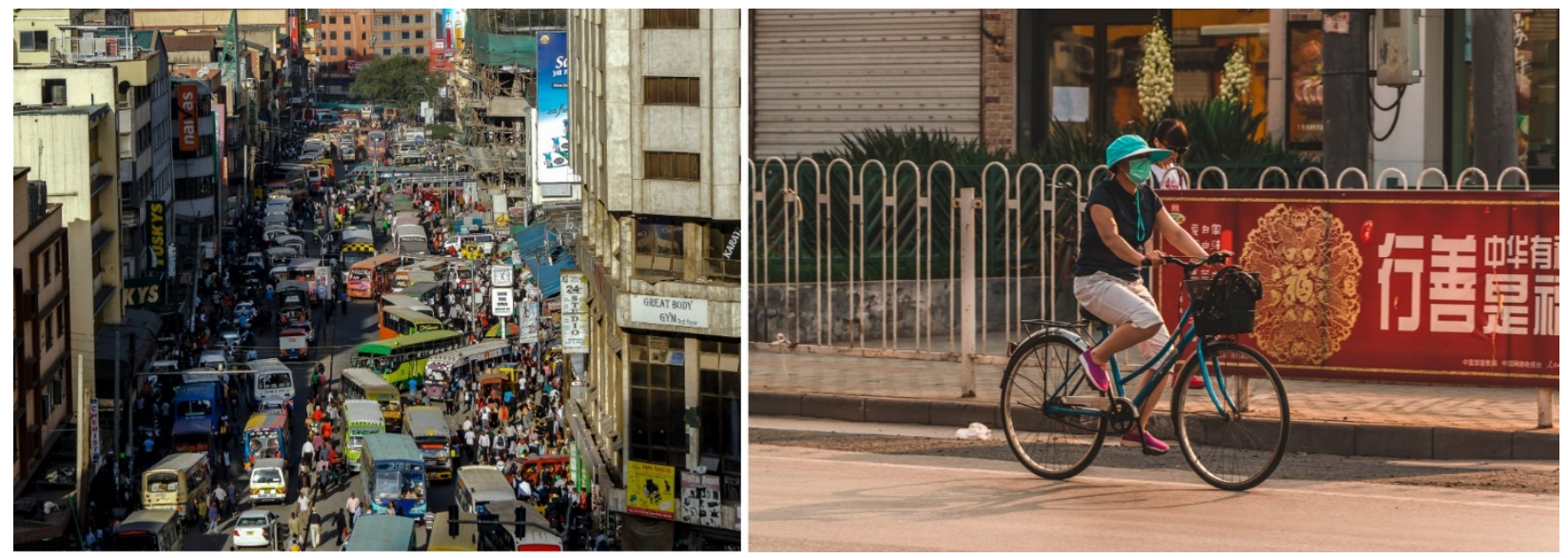

Figure 1 Urban populations are projected to double by 2030. How can we make current and future cities more sustainable while also maintaining and preserving biological diversity and ecosystem services? 
Integrating biomorphism into the design of new cities or improvement of old ones could mitigate the effects of anthropogenic urbanism while also providing new prototypes of how humans and nature can coexist in a more balanced and fair manner. Biomorphic urbanism could also help mitigate the effects of climate change on urban centers, including flooding, storms, sea-level rise, forest fires and drought. ${ }^{10,11}$ Examples of realized future cities include Seagull Island (China), Singapore, Silk City (Kuwait), and the Kitakyusho EcoTown project (Japan). ${ }^{11-13}$ More idealized, futuristic urban spaces include Ocean Spirals (Shimizu Corporation), Lilypad City (Vincent Callebaut), and the Venus Project (Jacque Fresco) (Fig. 2). ${ }^{13}$

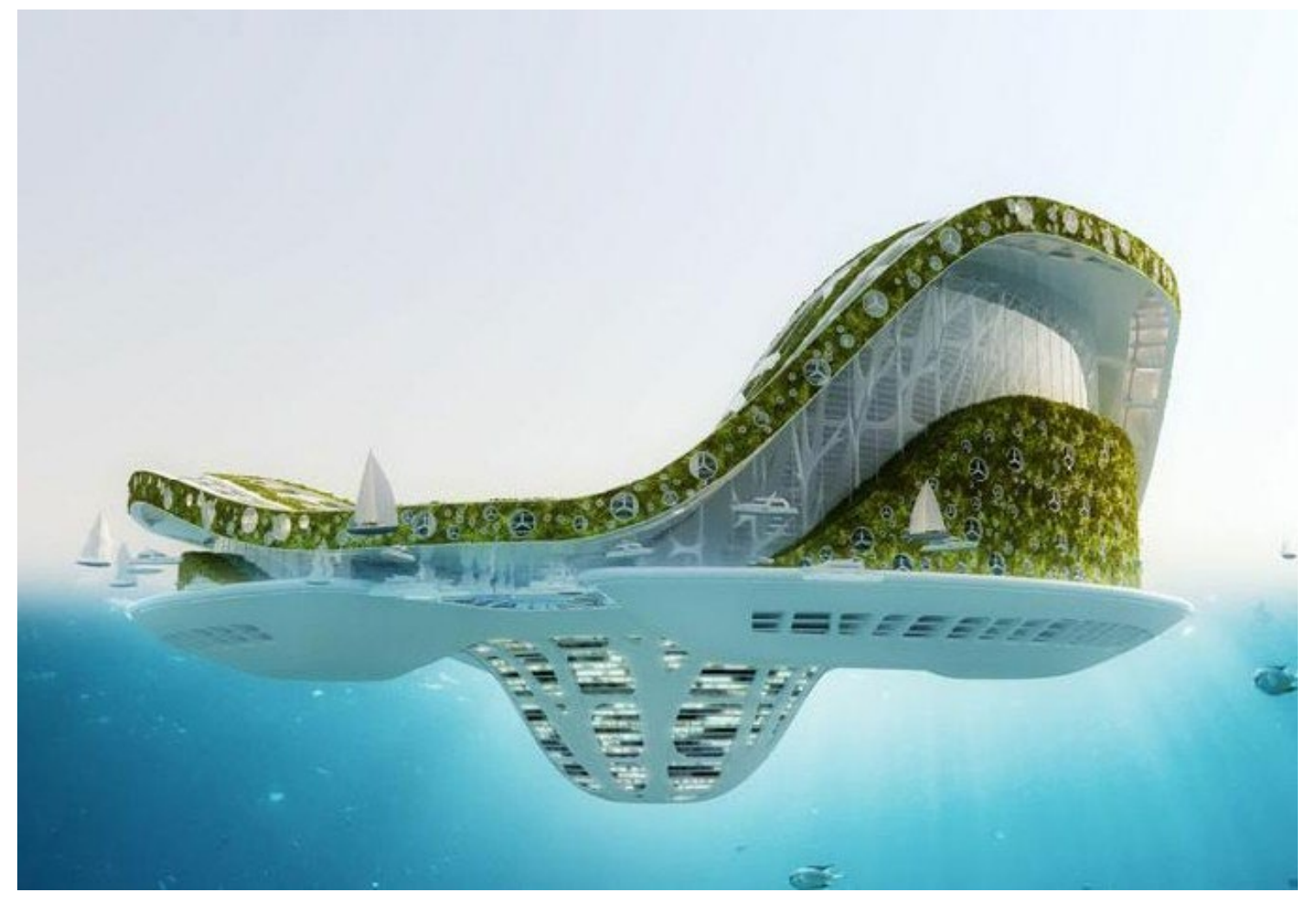

Figure 2 "Green" architects are increasingly embracing sustainability as a design concept, with plants playing a key role in shaping both building aesthetics and human quality of life. Pictured here is a rendering of the Lilypad City, designed by the architect Vincent Callebaut. The design of each unit is inspired by the shape of a lily pad; vegetation is a decorative feature. Image credit: Vincent Callebaut.

However, one of the greatest oversights of current future-city-thinking is the role of plants in terms of ecosystem service provisioning and human well-being. To date, sustainable architects think about vegetation in two main ways: 1 ) as a resource to cordon off or restore and 2) as an aesthetic medium. Here, I argue a third possibility: that we create entirely new buffer landscapes designed to perform specific functions that improve the sustainability of urban living, contribute to biodiversity conservation, and use resources more sustainably. I contend that we can use plants in a very directed manner to perform specific urban functions on different timescales (temporary vs. long-term). These specific urban functions relate to how cities are designed, how humans inhabit them, and how the natural environment and human activities interact. I argue these designed landscapes, termed loosely Function-Specific Plant Systems (FSPSs), can provide eight key services which could improve the sustainability of future cities. Moreover, I argue synthetic biology could expand these roles in the future. 


\section{Putting Plants to Work}

Designed Function-Specific Plant Systems (FSPSs) provide services that fall into three categories: Urban Landscape and Infrastructure; Biodiversity and the Environment; and Human Health. Table 1 lists the services under each category, the biological/ecological rational behind each service, examples of projects that provide data on the benefits of each service, and references which support the science behind each service. Many of these services provided by FSPSs align with the UN 2030 Sustainable Development Goals, namely SDG 6 Clean Water \& Sanitation, SDG 11 Sustainable Cities and Communities, SDG 14 Life Below Water, and SDG 15 Life on Land. ${ }^{14}$ Under the category of Urban Landscape and Infrastructure, FSPSs could be used to reduce flooding in coastal urban areas, stabilize shorelines from erosion, and reduce the impact of wildfires. The latter may become particularly important in areas of the Western US and Australia, where wild fire events are increasing annually. Under the category of Biodiversity and the Environment, FSPSs could be used to remove harmful industrial chemicals from waterways (e.g. rivers, lakes, storm run-off) while also providing habitats for native species. Finally, under the category of Human Health, FSPSs could be used to control pests like mosquitos, remove harmful pollutants (e.g. benzene) from urban environments, and potentially, alter the volatilomes of urban landscapes to promote human health and well-being.

Table 1: Services provided by Function-Specific Plant Systems (FSPSs). "Category" refers to the broad area of urban life impacted by each system. "Service" refers to the ecosystem service provided by each system. "Biological/Environmental Example" gives a brief overview of how each FSPS would 'work' in real life. "Example Projects/Studies" refer to the field and/or lab-based studies which support the service associated with specific plants/ecosystems.

\begin{tabular}{|l|l|l|l|l|}
\hline Category & Service & $\begin{array}{l}\text { Biological/Environmental } \\
\text { Example }\end{array}$ & Example Projects/Studies & References \\
\hline $\begin{array}{l}\text { Urban } \\
\text { Landscape and } \\
\text { Infrastructure }\end{array}$ & 1. Flood control & $\begin{array}{l}\text { Developing synthetic } \\
\text { wetlands to stabilize } \\
\text { waterfront soil banks and } \\
\text { serve as sinks for excess } \\
\text { water from floods and } \\
\text { storm water }\end{array}$ & $\begin{array}{l}\text { Smith Creek Drainage Basin } \\
\text { (Saskatchewan, Canada); } \\
\text { White Clay Creek watershed } \\
\text { (DE, USA); Barnegat Bay (NJ, } \\
\text { USA); Oakalla Biofiltration } \\
\text { System (Burnaby, B.C, } \\
\text { Canada) }\end{array}$ & $15-19$ \\
\cline { 2 - 6 } & 2. Soil stabilization & $\begin{array}{l}\text { Planting deep-rooted } \\
\text { grasses, ruderal plants, } \\
\text { and trees to prevent soil } \\
\text { loss from wind and } \\
\text { weather events }\end{array}$ & $\begin{array}{l}\text { Oregon Cascades (OR, USA); } \\
\text { De Mond Nature Reserve } \\
\text { (South Africa) }\end{array}$ & 20,21 \\
\cline { 2 - 6 } & 3. Fire control & $\begin{array}{l}\text { Planting barriers with } \\
\text { trees and shrubs resistant } \\
\text { to fire between urban } \\
\text { settlements and natural } \\
\text { vegetation }\end{array}$ & CypFire Project (Italy) & 22,23 \\
\hline $\begin{array}{l}\text { Biodiversity } \\
\text { and the } \\
\text { Environment }\end{array}$ & $\begin{array}{l}\text { 4. Water } \\
\text { treatment }\end{array}$ & $\begin{array}{l}\text { wetlands with plants } \\
\text { have roots that can filter, } \\
\text { hyperaccumulate and } \\
\text { metabolize industrial } \\
\text { toxins, pharmaceuticals, }\end{array}$ & $\begin{array}{l}\text { Gradisce (Slovenia); Piana } \\
\text { degli Albanesi (Sicily) }\end{array}$ & $24-28$ \\
\end{tabular}




\begin{tabular}{|c|c|c|c|c|}
\hline & & $\begin{array}{l}\text { heavy metals and } \\
\text { pathogens }\end{array}$ & & \\
\hline & $\begin{array}{l}\text { 5. Habitats for } \\
\text { indigenous } \\
\text { endangered } \\
\text { species }\end{array}$ & Native vegetation & $\begin{array}{l}\text { Forest Research Institute } \\
\text { Malaysia (Kepong); Tokyo, } \\
\text { Japan; Molonglo Valley } \\
\text { (Canberra, Australia); } \\
\text { Pachuca (Mexico) }\end{array}$ & $29-32$ \\
\hline \multirow[t]{3}{*}{ Human Health } & 6. Pest control & $\begin{array}{l}\text { Integrating plants that } \\
\text { ward off mosquitoes into } \\
\text { urban domestic and } \\
\text { recreational spaces }\end{array}$ & Kagera Region (Tanzania) & $33-42$ \\
\hline & 7. Air purification & $\begin{array}{l}\text { Developing green roofs } \\
\text { with plant and tree } \\
\text { species can absorb and } \\
\text { metabolize volatile } \\
\text { organic compounds } \\
\text { (VOCs) like benzene and } \\
\text { small particles }\end{array}$ & $\begin{array}{l}\text { Chicago (IL, USA); Singapore; } \\
\text { Guangzhou (China); Shanghi } \\
\text { (China) }\end{array}$ & $43-47$ \\
\hline & $\begin{array}{l}\text { 8. Human health } \\
\text { (volatilomes) }\end{array}$ & $\begin{array}{l}\text { Planting trees that give } \\
\text { off volatile compounds } \\
\text { (e.g. terpenoids) that } \\
\text { positively impact human } \\
\text { health through } \\
\text { modulation of the } \\
\text { immune system along } \\
\text { public transport systems }\end{array}$ & n.d. & 48,49 \\
\hline
\end{tabular}

The FSPSs described above could be incorporated into pre-existing and new urban designs in four ways. First, certain FSPSs could be used to develop "buffer zones" that surround certain urban features. For example, stands of cypress (Cupressus sempervirens) could be established around fire-prone areas ${ }^{22}$ while eucalyptus ${ }^{41}$ could be planted around residential areas in malaria-prone regions (Fig. 3). Second, plants and trees with specific functional traits could be incorporated into urban landscaping. For example, urban landscapers could integrate plane trees, ivy and ferns along urban walkways and around transit hubs to reduce the amount of small particulate matter and volatile organic compounds from automobiles. ${ }^{43}$ Similarly, when designing green walls, landscape architects could select plants known for sequestering and/or degrading predominant air pollutants, such as BTEX, solvents, pesticides, adhesives, coatings and cleaning agents. ${ }^{57}$ Third, FSPSs could be incorporated into green architecture. Architects routinely incorporate plants into building designs for aesthetic reasons, yet being more conscious about what plants and trees are used could increase the impact of these features on human health and the environment. Research on volatilomes is in its infancy, ${ }^{58}$ but research suggests that the compounds produced by plants and bacteria can impact human health and well-being. ${ }^{49,59,60}$ These VOCs (such as terpenoids) are highly lipophilic and can pass the blood-brain barrier, causing neurophysiological and behavioral changes in mammals (such as reduced anxiety and improved memory), while also reducing risk/duration of infections and other illnesses. ${ }^{49}$ Potentially, selection of plants in urban residential units can be guided by these principles. Finally, FSPSs could be integrated into urban art installations. ${ }^{61}$ These installations could play 
with form and function, culture and identity, conservation and education, thereby pioneering new ways of integrating plants into urban landscapes.
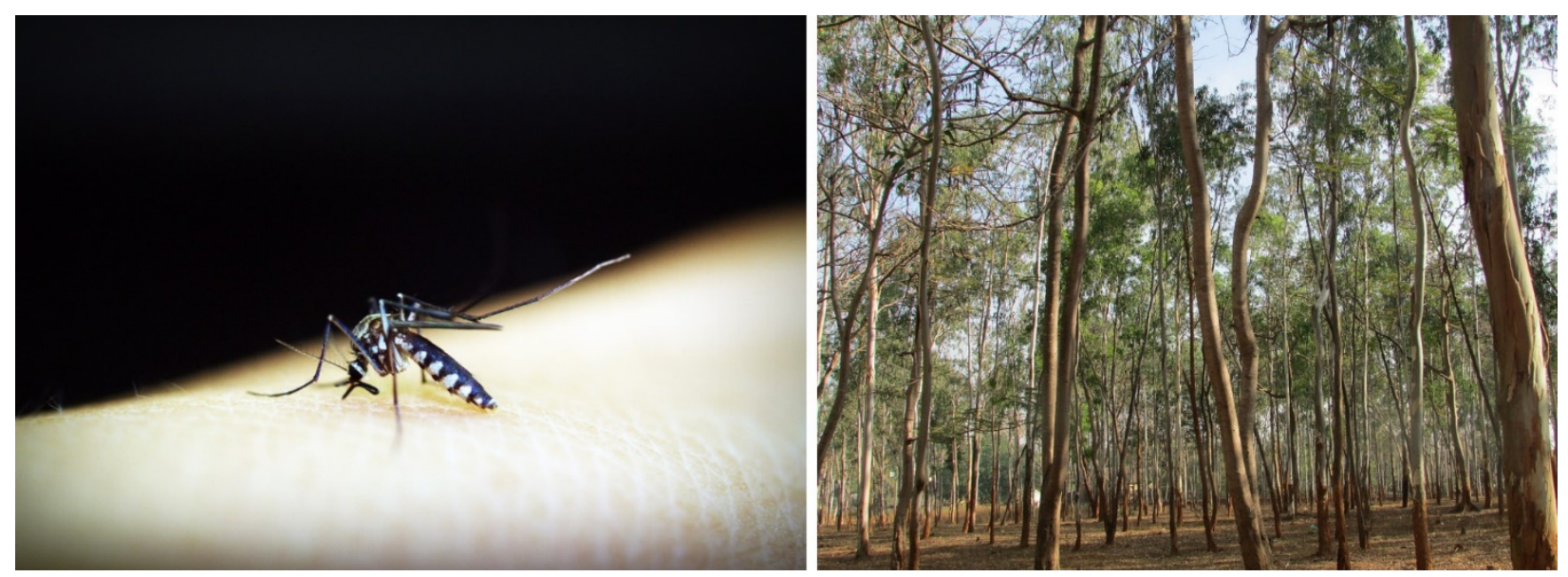

Figure 3 Plants, natural or genetically enhanced, could be used in a targeted manner to solve problems faced by urban communities. Examples include planting eucalyptus trees, or other plants traditionally used for mosquito management, in buffer zones around residential areas to reduce exposure to malaria-bearing mosquitoes.

Advances in plant synthetic biology could also expand these roles. ${ }^{50-52}$ Examples include augmenting the native abilities of plants to perform specific functions (such as biotransformation of industrial toxins ${ }^{53}$ or production of insect-repellant volatiles ${ }^{41}$ ) by over-expressing key enzymes or by altering plant metabolomes (Fig. 4); developing new raw materials on-site that meet the needs of urban construction and consumption ${ }^{54}$; locally producing natural plant-derived colorants for urban textile and food industries to replace toxic chemicals ${ }^{55}$; and genetically engineering plants to use urban resources (water, nitrogen etc.) more sustainably to produce drugs/food for urban populations. ${ }^{56}$

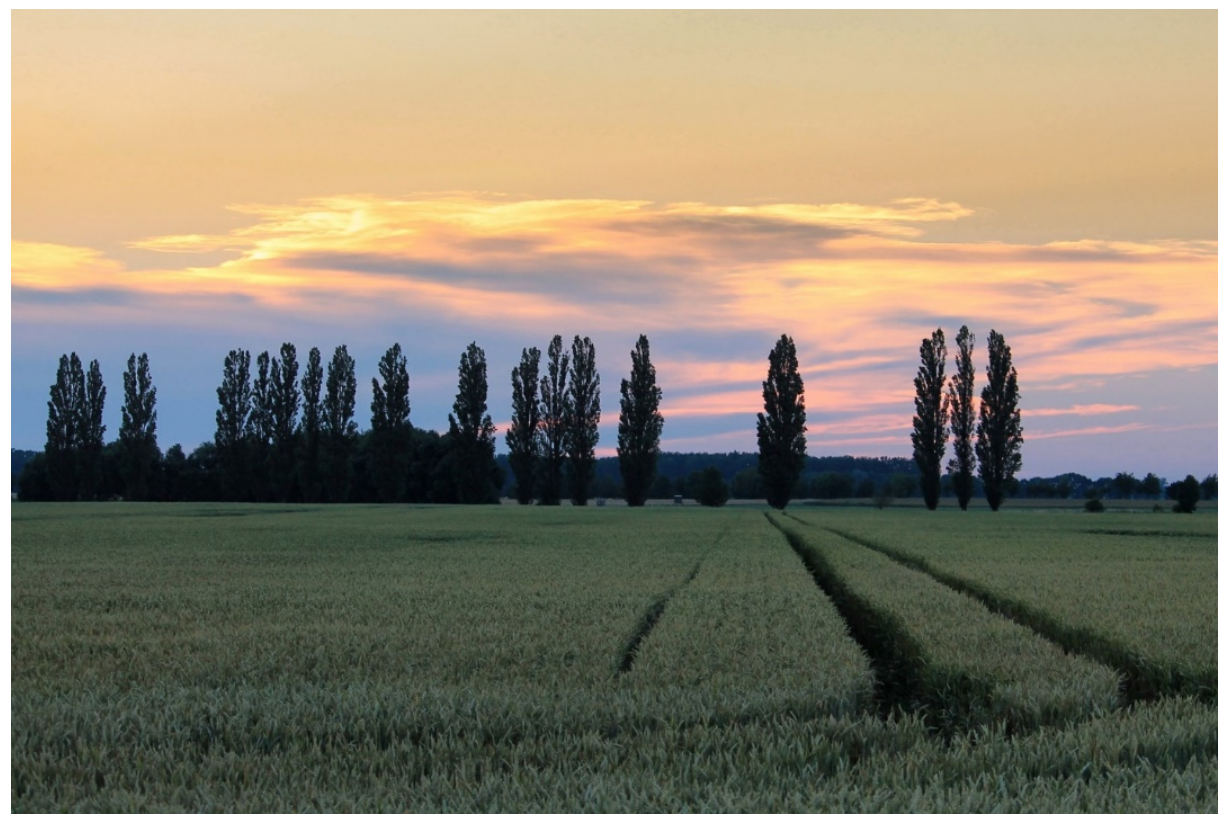

Figure 4 Engineering plants to perform current or new ecological roles will expand in the near future thanks to advances in synthetic biology. A good example is engineering poplar roots to over-express enzymes involved in industrial chemical degradation for enhanced remediation of contaminated land. 


\section{Challenges to Implementation}

Implementing FSPSs face three key challenges: sustainable design, cost effectiveness, and environmental impact.

The design of FSPSs is key to extracting the greatest benefits from the plant systems while minimizing their carbon footprint. Design includes everything from sourcing raw materials to intended use and end of life. Whether new objects, materials, or buildings, design accounts for an estimated $80 \%$ of their environmental impact. ${ }^{62}$ The materials used in their construction should be organic where possible. A key charge against living walls and green roofs is that the materials used in their construction are derived from fossil-fuels, ${ }^{63}$ minimizing the carbon they offset (but not other services, such as reduced energy use, air purification, and removing pollutants from storm water drainage). ${ }^{64}$ One possibility would be to use bioplastics, cellulose made from bacteria, or mycelium-based materials from fungi. ${ }^{65-68}$

Another critical aspect of design is which plants to use. On the one hand, native plants are ideal because they are well-suited to local environments. However, non-native plants have a key advantage, namely increased capacity to perform a given service (e.g. air purification). Whether native or non-native plants are used, central to the design of FSPSs is the focus on principles instead of specific plants. For example, plants sown onto coastlines to control soil erosion may change over the years based on changing local environmental conditions (e.g. salinity, temperature, etc.). GIS could play a key role in the design of FSPSs in the future. Using GIS, we can geospatially map climatological, biological, chemical, and plant functional trait data to model and predict how FSPSs might respond in multiple circumstances. ${ }^{69-72}$ Employing key design concepts from ecological engineering-such as self-design and systems theory-could also be used to design more complex, multi-species FSPSs that are self-sustaining, resilient, generate zero waste, recycle nutrients, and require minimal management. ${ }^{73-75}$

The intended end-user of a FSPS should also be taken into account. Key variables to consider include lifespan and location. For example, a green roof might be designed to last 10 years while a water purification system would be in use on a much longer time-frame (e.g. 20-50 years). Location and enduser (e.g. domestic, civic, industrial) will also determine the size, composition, and design of FSPSs. For example, plant-based water purification systems for single-family households will take a much different form from those used to purify water from industrial sites.

Management of FSPSs must also be cost effective. Two methods currently used to green cities-living walls and green roofs-provide multiple amenities (e.g. reduced energy use from heating/cooling; improved air quality; storm drainage) yet some would argue that the design, cost and maintenance of these structures outweighs their benefits. Both features rely on the use of non-degradable polymers for construction. The construction and annual maintenance of these structures can also be up to four times more expensive than alternatives (such as using attic floor insulation or simply planting more trees). ${ }^{76,77}$ At all times, Life Cycle Assessments (LCA) can be used to determine the economic cost and environmental benefit of each FSPS, with the design modified accordingly for maximum benefit and least cost. ${ }^{78}$ One challenge with using LCAs as a benchmark, however, is our current inability to put a monetary value on the services many plants provide (e.g. air purification, modulation of human immune system). 
The short- and long-term effects of synthetic ecosystems FSPSs on existing ecosystems must also be monitored and mitigated where needed. For example, would planting cypress fire buffers in Bay-area fireprone cities lead to a decline in native bird species? Small scale field trials, long term data collection, and monitoring ${ }^{79}$ can be used to quantify changes in ecosystem services/provisioning and could be used to determine the risks and benefits of a FSPS in a given geographic location.

\section{Integrating Plants into Urban Design}

We need to think about how plants will fit into future cities models. Greater collaboration between plant scientists, ecologists, architects and engineers is needed to understand how we can translate knowledge of ecological ideas/processes into products/services for future urban societies. This collaboration is also needed to ensure plants and the functions they perform can be scaled up to city-level and that their impact (benefit) outweighs their cost. As such, field trials will become increasingly important to test whether principles of ecological engineering hold up under real conditions before expanding to entire urban landscapes. How these units are designed will be critical to how they function and how they are experienced. Working with artists and designers will also allow a re-imagining of urban landscapes which can push the boundaries of how form, function and aesthetics can go together.

Former industrial areas are good places to test out some of these designs, as these landscapes are currently under re-design and could benefit from some of the services (e.g. water purification) listed above. The FSPSs described above could also be incorporated into urban development in rapidly expanding low-economic income countries, where city re-design is underway and funding is readily available. Countries with the greatest area of urban land cover (5\% as of 2000)-including Bahrain, Belgium, Netherlands, the UK, Italy and Germany ${ }^{5}$-could also stand to benefit from supporting research on the development and local application of FSPSs.

While not a silver bullet, a more nuanced incorporation of plants into urban design will bring us one step closer to mitigating the effects of urbanism on the natural environment and human health in the near future.

\section{References}

1. National Geographic. The Cities Issue. Magazine vol. 235 (2019).

2. Beatley, T. \& Newman, P. Biophilic Cities Are Sustainable, Resilient Cities. Sustainability 5, 3328-3345 (2013).

3. Kindel, P. Biomorphic Urbanism: A Guide for Sustainable Cities. Medium

https://medium.com/@SOM/biomorphic-urbanism-a-guide-for-sustainable-cities4a1da72ad656 (2019). 
4. Pedersen Zari, M. Understanding and designing nature experiences in cities: a framework for biophilic urbanism. Cities Health 1-12 (2019) doi:10.1080/23748834.2019.1695511.

5. Angel, S., Parent, J., Civco, D. L., Blei, A. \& Potere, D. The dimensions of global urban expansion: Estimates and projections for all countries, 2000-2050. Prog. Plan. 75, 53-107 (2011).

6. McPhearson, T. et al. Advancing Urban Ecology toward a Science of Cities. BioScience 66, $198-212(2016)$.

7. Su, Z., Zhang, R. \& Qiu, J. Decline in the diversity of willow trunk-dwelling weevils (Coleoptera: Curculionoidea) as a result of urban expansion in Beijing, China. J. Insect Conserv. 15, 367-377 (2011).

8. Hilty, J. A., Brooks, C., Heaton, E. \& Merenlender, A. M. Forecasting the effect of land-use change on native and non-native mammalian predator distributions. Biodivers. Conserv. 15, 2853 (2006).

9. Seto, K. C., Güneralp, B. \& Hutyra, L. R. Global forecasts of urban expansion to 2030 and direct impacts on biodiversity and carbon pools. Proc. Natl. Acad. Sci. 109, 16083-16088 (2012).

10. Leichenko, R. Climate change and urban resilience. Curr. Opin. Environ. Sustain. 3, 164-168 (2011).

11. Riffat, S., Powell, R. \& Aydin, D. Future cities and environmental sustainability. Future Cities Environ. 2, 1 (2016).

12. National Geographic. Cities of the Future. Natl. Geogr. 235, 20 (2019). 
13. McDonnell, M. J. \& MacGregor-Fors, I. The ecological future of cities. Science 352, 936-938 (2016).

14. United Nations. 17 Goals to Transform Our World. https://www.un.org/sustainabledevelopment/ (2018).

15. Brydon, J., Roa, M. C., Brown, S. J. \& Schreier, H. Integrating Wetlands into Watershed Management: Effectiveness of Constructed Wetlands to Reduce Impacts from Urban Stormwater. in Environmental Role of Wetlands in Headwaters (eds. Krecek, J. \& Haigh, M.) 143-154 (Springer Netherlands, 2006). doi:10.1007/1-4020-4228-0_12.

16. Pattison-Williams, J. K., Pomeroy, J. W., Badiou, P. \& Gabor, S. Wetlands, Flood Control and Ecosystem Services in the Smith Creek Drainage Basin: A Case Study in Saskatchewan, Canada. Ecol. Econ. 147, 36-47 (2018).

17. Narayan, S. et al. The Value of Coastal Wetlands for Flood Damage Reduction in the Northeastern USA. Sci. Rep. 7, 1-12 (2017).

18. Levy, S. The Ecology of Artificial Wetlands. BioScience 65, 346-352 (2015).

19. Scientists Monitor New Wetland Designed for Flood Control and Improved Stream Habitat. Stroud Water Research Center https://stroudcenter.org/news/new-wetland-flood-control/ (2018).

20. Dryess, C. T. Grass-legume mixtures for erosion control along forest roads in western Oregon. J. Soil Water Conserv. 30, 169-173 (1975).

21. Lubke, R. A. \& Hertling, U. M. The role of European marram grass in dune stabilization and succession near Cape Agulhas, South Africa. J. Coast. Conserv. 7, 171-182 (2001). 
22. Della Rocca, G., Danti, R., Raddi, P., Moya, B. \& Moya, J. Implementation of the 'cypress system' as a green firewall. For. Méditerr XXXV 3, 275-280 (2014).

23. Della Rocca, G. et al. Possible land management uses of common cypress to reduce wildfire initiation risk: a laboratory study. J. Environ. Manage. 159, 68-77 (2015).

24. Kivaisi, A. K. The potential for constructed wetlands for wastewater treatment and reuse in developing countries: a review. Ecol. Eng. 16, 545-560 (2001).

25. Vrhovšek, D., Kukanja, V. \& Bulc, T. Constructed wetland (CW) for industrial waste water treatment. Water Res. 30, 2287-2292 (1996).

26. Rousseau, D. P. L., Lesage, E., Story, A., Vanrolleghem, P. A. \& De Pauw, N. Constructed wetlands for water reclamation. Desalination 218, 181-189 (2008).

27. Coleman, J. et al. Treatment of Domestic Wastewater by Three Plant Species in Constructed Wetlands. Water. Air. Soil Pollut. 128, 283-295 (2001).

28. Licata, M., Gennaro, M. C., Tuttolomondo, T., Leto, C. \& Bella, S. L. Research focusing on plant performance in constructed wetlands and agronomic application of treated wastewater - A set of experimental studies in Sicily (Italy). PLOS ONE 14, e0219445 (2019).

29. Carbó-Ramírez, P. \& Zuria, I. The value of small urban greenspaces for birds in a Mexican city. Landsc. Urban Plan. 100, 213-222 (2011).

30. Ikin, K., Knight, E., Lindenmayer, D. B., Fischer, J. \& Manning, A. D. The influence of native versus exotic streetscape vegetation on the spatial distribution of birds in suburbs and reserves. Divers. Distrib. 19, 294-306 (2013).

31. Idilfitri, S. \& Mohamad, N. H. N. Role of Ornamental Vegetation for Birds' Habitats in Urban Parks: Case Study FRIM, Malaysia. Procedia - Soc. Behav. Sci. 68, 894-909 (2012). 
32. Matsuba, M., Nishijima, S. \& Katoh, K. Effectiveness of corridor vegetation depends on urbanization tolerance of forest birds in central Tokyo, Japan. Urban For. Urban Green. 18, 173-181 (2016).

33. Sukumar, K., Perich, M. J. \& Boobar, L. R. Botanical derivatives in mosquito control: a review. J. Am. Mosq. Control Assoc. 7, 210-237 (1991).

34. Chaithong, U. et al. Larvicidal effect of pepper plants on Aedes aegypti (L.) (Diptera: Culicidae). J. Vector Ecol. 31, 138-144 (2006).

35. Bowers, W. S., Sener, B., Evans, P. H., Bingol, F. \& Erdogan, I. Activity of Turkish Medicinal Plants Against Mosquitoes Aedes aegypti and Anopheles gambiae. Int. J. Trop. Insect Sci. 16, 339-342 (1995).

36. Lukwa, N., Nyazema, N. Z., Curtis, C. G., Mwaiko, G. L. \& Chandiwana, S. K. People's perceptions about malaria transmission and control using mosquito repellent plants in a locality in Zimbabwe. Cent. Afr. J. Med. 45, (1999).

37. Jaenson, T. G. T., Pålsson, K. \& Borg-Karlson, A.-K. Evaluation of Extracts and Oils of Mosquito (Diptera: Culicidae) Repellent Plants from Sweden and Guinea-Bissau. J. Med. Entomol. 43, 113-119 (2006).

38. Mng'ong'o, F. C. et al. Repellent Plants Provide Affordable Natural Screening to Prevent Mosquito House Entry in Tropical Rural Settings-Results from a Pilot Efficacy Study. PLOS ONE 6, e25927 (2011).

39. Pålsson, K. \& Jaenson, T. G. T. Plant products used as mosquito repellents in Guinea Bissau, West Africa. Acta Trop. 72, 39-52 (1999).

40. Dhang, P. Urban Insect Pests: Sustainable Management Strategies. (CABI, 2014). 
41. Tyagi, B. K. Advances in Vector Mosquito Control Technologies, with Particular Reference to Herbal Products. in Herbal Insecticides, Repellents and Biomedicines: Effectiveness and Commercialization (eds. Vijay Veer \& Gopalakrishnan, R.) 1-9 (Springer India, 2016). doi:10.1007/978-81-322-2704-5_1.

42. Omolo, M. O., Okinyo, D., Ndiege, I. O., Lwande, W. \& Hassanali, A. Repellency of essential oils of some Kenyan plants against Anopheles gambiae. Phytochemistry 65, 2797-2802 (2004).

43. Claudio, L. Planting Healthier Indoor Air. Environ. Health Perspect. 119, a426-a427 (2011).

44. Nowak, D. J., Crane, D. E. \& Stevens, J. C. Air pollution removal by urban trees and shrubs in the United States. Urban For. Urban Green. 4, 115-123 (2006).

45. Yang, J., Yu, Q. \& Gong, P. Quantifying air pollution removal by green roofs in Chicago. Atmos. Environ. 42, 7266-7273 (2008).

46. Jim, C. Y. \& Chen, W. Y. Assessing the ecosystem service of air pollutant removal by urban trees in Guangzhou (China). J. Environ. Manage. 88, 665-676 (2008).

47. Yin, S. et al. Quantifying air pollution attenuation within urban parks: An experimental approach in Shanghai, China. Environ. Pollut. 159, 2155-2163 (2011).

48. Li, Q. et al. Effect of Phytoncide from Trees on Human Natural Killer Cell Function. Int. J. Immunopathol. Pharmacol. 22, 951-959 (2009).

49. E. Maffei, M., Gertsch, J. \& Appendino, G. Plant volatiles: Production, function and pharmacology. Nat. Prod. Rep. 28, 1359-1380 (2011).

50. Küken, A. \& Nikoloski, Z. Computational Approaches to Design and Test Plant Synthetic Metabolic Pathways. Plant Physiol. 179, 894-906 (2019). 
51. French, K. E. Harnessing synthetic biology for sustainable development. Nat. Sustain. 2, 250-252 (2019).

52. Mortimer, J. C. Plant synthetic biology could drive a revolution in biofuels and medicine. Exp. Biol. Med. 244, 323-331 (2019).

53. Doty, S. L. et al. Enhanced metabolism of halogenated hydrocarbons in transgenic plants containing mammalian cytochrome P450 2E1. Proc. Natl. Acad. Sci. U. S. A. 97, 6287-6291 (2000).

54. Sakamoto, S. et al. Complete substitution of a secondary cell wall with a primary cell wall in Arabidopsis. Nat. Plants 4, 777-783 (2018).

55. Appelhagen, I. et al. Colour bio-factories: Towards scale-up production of anthocyanins in plant cell cultures. Metab. Eng. 48, 218-232 (2018).

56. López-Arredondo, D., González-Morales, S. I., Bello-Bello, E., Alejo-Jacuinde, G. \& Herrera, L. Engineering food crops to grow in harsh environments. F1000Research 4, (2015).

57. McDonald, B. C. et al. Volatile chemical products emerging as largest petrochemical source of urban organic emissions. Science 359, 760-764 (2018).

58. Giannoukos, S., Agapiou, A., Brkić, B. \& Taylor, S. Volatolomics: A broad area of experimentation. J. Chromatogr. B 1105, 136-147 (2019).

59. Ljunggren, J. et al. Yeast Volatomes Differentially Affect Larval Feeding in an Insect Herbivore. Appl. Environ. Microbiol. 85, (2019).

60. Liddicoat, C. et al. Naturally-diverse airborne environmental microbial exposures modulate the gut microbiome and may provide anxiolytic benefits in mice. Sci. Total Environ. 701, 134684 (2020). 
61. Sachdev, G. Engaging with plants in an urban environment through street art and design. PLANTS PEOPLE PLANET 1, 271-289 (2019).

62. Childers, D. L. et al. An Ecology for Cities: A Transformational Nexus of Design and Ecology to Advance Climate Change Resilience and Urban Sustainability. Sustainability 7, 3774-3791 (2015).

63. Bianchini, F. \& Hewage, K. How "green" are the green roofs? Lifecycle analysis of green roof materials. Build. Environ. 48, 57-65 (2012).

64. Pulselli, R. M., Pulselli, F. M., Mazzali, U., Peron, F. \& Bastianoni, S. Emergy based evaluation of environmental performances of Living Wall and Grass Wall systems. Energy Build. 73, 200-211 (2014).

65. Florea, M. et al. Engineering control of bacterial cellulose production using a genetic toolkit and a new cellulose-producing strain. Proc. Natl. Acad. Sci. U. S. A. 113, E3431-E3440 (2016).

66. Munoz, L. E. A. \& Riley, M. R. Utilization of cellulosic waste from tequila bagasse and production of polyhydroxyalkanoate (PHA) bioplastics by Saccharophagus degradans. Biotechnol. Bioeng. 100, 882-888 (2008).

67. Sagnelli, D. et al. Plant-crafted starches for bioplastics production. Carbohydr. Polym. 152, 398-408 (2016).

68. Abhijith, R., Ashok, A. \& Rejeesh, C. R. Sustainable packaging applications from mycelium to substitute polystyrene: a review. Mater. Today Proc. 5, 2139-2145 (2018). 
69. Grêt-Regamey, A., Celio, E., Klein, T. M. \& Wissen Hayek, U. Understanding ecosystem services trade-offs with interactive procedural modeling for sustainable urban planning. Landsc. Urban Plan. 109, 107-116 (2013).

70. Masson, V. et al. Adapting cities to climate change: A systemic modelling approach. Urban Clim. 10, 407-429 (2014).

71. Jackson, B. et al. Polyscape: A GIS mapping framework providing efficient and spatially explicit landscape-scale valuation of multiple ecosystem services. Landsc. Urban Plan. 112, $74-88$ (2013).

72. Nemec, K. T. \& Raudsepp-Hearne, C. The use of geographic information systems to map and assess ecosystem services. Biodivers. Conserv. 22, 1-15 (2013).

73. Mitsch, W. J. What is ecological engineering? Ecol. Eng. 45, 5-12 (2012).

74. Bergen, S. D., Bolton, S. M. \& L. Fridley, J. Design principles for ecological engineering. Ecol. Eng. 18, 201-210 (2001).

75. Costanza, R. Ecosystem health and ecological engineering. Ecol. Eng. 45, 24-29 (2012).

76. Yok Tan, P. \& Sia, A. A pilot green roofresearch project in Singapore. in Proc. of 3rd North American Green RoofConference: Greening rooftops for sustainablecommunities, Washington, DC. 4-6 May 2005. 399-415 (Cardinal Group, 2005).

77. Blackhurst Michael, Hendrickson Chris \& Matthews H. Scott. Cost-Effectiveness of Green Roofs. J. Archit. Eng. 16, 136-143 (2010).

78. Guinée, J. B. et al. Life Cycle Assessment: Past, Present, and Future. Environ. Sci. Technol. 45, 90-96 (2011). 
79. Tilman, D. Ecological Experimentation: Strengths and Conceptual Problems. in Long-Term Studies in Ecology: Approaches and Alternatives (ed. Likens, G. E.) 136-157 (Springer New York, 1989). doi:10.1007/978-1-4615-7358-6_6. 